\title{
Measuring competences in school-leaver surveys
}

Citation for published version (APA):

van Loo, J. B., \& Semeijn, J. H. (2001). Measuring competences in school-leaver surveys.

Researchcentrum voor Onderwijs en Arbeidsmarkt, Faculteit der Economische Wetenschappen. ROA Research Memoranda No. 2E https://doi.org/10.26481/umaror.200102E

Document status and date:

Published: 01/01/2001

DOI:

10.26481/umaror.200102E

Document Version:

Publisher's PDF, also known as Version of record

\section{Please check the document version of this publication:}

- A submitted manuscript is the version of the article upon submission and before peer-review. There can be important differences between the submitted version and the official published version of record.

People interested in the research are advised to contact the author for the final version of the publication, or visit the DOI to the publisher's website.

- The final author version and the galley proof are versions of the publication after peer review.

- The final published version features the final layout of the paper including the volume, issue and page numbers.

Link to publication

\footnotetext{
General rights rights.

- You may freely distribute the URL identifying the publication in the public portal. please follow below link for the End User Agreement:

www.umlib.nl/taverne-license

Take down policy

If you believe that this document breaches copyright please contact us at:

repository@maastrichtuniversity.nl

providing details and we will investigate your claim.
}

Copyright and moral rights for the publications made accessible in the public portal are retained by the authors and/or other copyright owners and it is a condition of accessing publications that users recognise and abide by the legal requirements associated with these

- Users may download and print one copy of any publication from the public portal for the purpose of private study or research.

- You may not further distribute the material or use it for any profit-making activity or commercial gain

If the publication is distributed under the terms of Article $25 \mathrm{fa}$ of the Dutch Copyright Act, indicated by the "Taverne" license above, 


\title{
Measuring Competences in School-leaver Surveys
}

\author{
ROA-RM-2001/2E \\ Jasper van Loo and Judith Semeijn
}

Research Centre for Education and the Labour Market

Faculty of Economics and Business Administration Maastricht University

Maastricht, February 2001 
We wish to thank all members of ROA's competence group. This group, which includes members from both of ROA's research departments as well as some external experts, has the mission to investigate the concept of competence both in theoretical and empirical ways. Its main goal is to advance the usefulness of the competence questions in ROA's large-scale school-leaver surveys for the Netherlands. This paper has benefited a great deal from the ideas and comments from the members of ROA's competence group: Jim Allen, Lex Borghans, Karin Jacob, Ger Ramaekers, Jos Sanders, Bert Toolsema and Rina Vaatstra. In addition, we thank the participants of the ILM conference in Aberdeen, Scotland (December 11-12, 2000) and Andries de Grip for useful comments.

ISBN 90-5321-305-8

Sec01.040.doc 


\section{Contents}

Pagina

1 Introduction

2 Competences and competence measurement: an overview from the literature

2.1 Competence Definitions

2.2 Competence Classifications

2.3 Competence Measurement Perspectives

2.4 Competence Development

2.5 Summary: Problems in Competence Measurement

3 Competence Measurement in School-leaver Surveys

3.1 Measurement Methodologies

3.2 Recent Competence Measurement Research, Some Examples

3.3 Practical Measurement Problems

4 Measuring Competences in ROA's School-leaver Surveys

5 Empirical results from comparing two competence measurement methodologies

5.1 'Importance' vs 'Use' methodology

5.2 'Attention' vs 'Top3' methodology

5.3 Survey efficiency in terms of wage prediction: the group of school-leavers as a whole

5.4 Differentiating by Type of Education and Occupation

6 Conclusions and considerations for further research

References

Appendix A: Competence items in the 1998 and 1999 surveys 



\section{Introduction}

The measurement of competences is a relatively new topic in the economic science. In the past, economists have usually measured worker competences by educational background, tenure, or other simple quantifiable indicators. In the transition from the industrial to the knowledge economy, however, this classical approach has become rather unsatisfactory. Individual labour market performance is no longer dependent on just the individual's initial education, since todays labour market requires continuous learning and development throughout the career. Employability has become a key concept in the knowledge economy, and the traditional lifetime employment career in a single firm has been replaced by what has been termed the protean career (Hall and Moss, 1998). In such a career, the person, not the firm, is the managing agent. In order to measure or predict career success, unidimensional indicators such as educational background that economists have used in the past are no longer sufficient. In the modern economy, skills and knowledge are the main factors in production, and the measurement of competences is a logical step in determining and predicting individual labour market success more accurately and reliably.

Although the concept of competences is widely used in today's research related to education, training and work, the meaning of competences and issues related to measurement are still subject to confusion and discussion. In this paper, the topic of measurement of competences in school-leaver surveys will be addressed. The goal of the paper is to focus on competence measurement in school-leaver research in both a theoretical and an empirical manner. Our purpose will be fourfold. Firstly, we review the literature on the competence concept and competence measurement. Secondly, we attempt to assess the implications from this for competence measurement in school-leaver surveys. From this, we develop a working definition for the competence concept within the field of school-leaver research. Using this definition we then explain how, in our view, school-leaver competences can be measured in a satisfactory manner. This measurement strategy is then assessed empirically by comparing it with the methodology used before. Here we compare empirically two cohorts of graduates (1998 and 1999) in terms of questionnaire efficiency and wage prediction.

School-leaver research in the Netherlands has been carried out for a number of years within the Research Centre for Education and the Labour Market (ROA). The broad objective of this research is to investigate the labour market position and the school-to-work transition of school-leavers. Many items in the survey are meant to get a clear view of this position. Since the ROA-surveys cover a large part of the educational system, it is possible to calculate 'rate of returns' for different types and levels of education. Attention has also been given to provide information on competences that were learned in a satisfactory way during school and those items that have not been adequately addressed in education. This has been used as a policy instrument for determining if more attention is needed in some area of expertise.

Until 1998, the competence items in ROA's school-leaver surveys have been formulated in terms of job characteristics. The number of competences questioned has been quite high, partly due to requests from policy makers, partly due to academic interest. This competence 
measurement strategy has, in the past, yielded rather limited empirical results. There is more potential for competence research by improving those parts of the school-leaver survey questionnaire that are concerned with competence measurement. The resulting improved information can be useful for educational institutions, policy makers, as well as academic researchers.

The development of a successful competence measurement strategy first requires a sound understanding of the competence concept itself. Therefore, in this paper we first review the competence concept and competence measurement in general from the relevant literature in section 2. In section 3, issues in competence measurement in school-leaver surveys will be discussed. Section 4 deals with some of the empirical problems encountered in the 1998 and earlier surveys which led to the development of the new competence measurement methodology in 1999. The empirical results were obtained from a comparative study of two (1998 and 1999) cohorts of graduates and can be found in section 5. Section 6, finally, concludes and summarises our main results.

\section{Competences and competence measurement: an overview from the literature}

There is hardly any concept in the literature that has so many different definitions as the competence concept. This is partly due to the fact that competences are relevant in a number of distinct research fields with different disciplinary roots. Since the development of a successful competence measurement strategy in the context of school-leaver research requires that we first know more about the competence concept itself, we try to summarise the main insights on competences in these fields from the literature. This may be useful for our own competence definition and measurement strategy in the context of school-leaver research. In section 2.1, we will first review some considerations from the literature and provide a short historical overview of the concept. The classification of competences is addressed in section 2.2. In section 2.3, we review the various disciplinary perspectives on competences. Section 2.4 presents some insights from the competence development literature. Finally, we conclude by summarizing the key theoretical problems in competence measurement in section 2.5.

\subsection{Competence Definitions}

What is (a) competence? Stevenson (1996) notes that the competence-concept has different meanings in ordinary, academic and vocational educational and training practice. These meanings also have historical dimensions, implying that the definition of competence has evolved over time. Stevenson (1996) makes a distinction between normative constructions of competence (the everyday construction, the vocational and training construction and the academic construction of competence), philosophical considerations, considerations from cognitive psychology and considerations of the competence-based education and training (CBT) movement. 
The everyday construction of competence is the capacity to undertake an activity well (e.g. a competent librarian), where 'well' means that a goal has been reached and that this goal has been reached in a skilful way. In the vocational and training construction of competence, competence refers to the capacity to perform defined and predictable tasks according to a pre-specified standard. The bases for the standards are particular ideas of what constitutes the 'good', which using this definition makes competence a normative concept. In academia, competence does not refer only to mere 'skills' but also to more abstract capacities like abstract thinking, generation of new knowledge, rigour and reflection. In the academic meaning of the competence concept, 'appropriate action' has a distinct meaning and is therefore normative as well.

In philosophy, the normative nature of the concept is addressed, because of its concern with the nature of knowledge, reality and ethics. Philosophy makes a clear distinction between valued purposes and valued personal attributes, which are normative aspects of competence. Carr (1993) distinguishes the causal aspects of competence (dispositions) as characteristics that enable us to perform specifiable functions either by training, or by natural endowment. These include skills, habits and functions that enable mechanical efficiency. On the other hand, there are holistic aspects of competence which are normative and enable practical action through voluntary and deliberate exercise of principle judgement, 'good' or 'right' action. The key contribution of philosophy is that it recognises both technical and value dimensions of competence.

In cognitive psychology, competence is sometimes defined as a developmental stage between novice and expert action, sometimes in terms of expertise itself. Glaser (1990) sees competence as characterised by efficiency and principled understanding, by both fast pattern recognition and conscious monitoring. Principled refers to an organisation of knowledge, in terms of structural principles, rather than having normative connotations of rightness. Therefore, the definition connotes to what is usually designated in cognitive psychology as expertise. This label carries with it connotations of adaptive, generative and innovative activity. Competence is then seen as being enabled by compiled specific procedures, general problem solving procedures and principled understanding.

In competence-based education and training (CBT) the construction of competence is explicitly normative. The problem is in the nature of the norms that are adopted, often by spokespersons of industrial bodies. Secondly, knowing is equated to doing, although in more recent manifestations knowledge is regarded more separately.

Where does the competence concept originate? The competence-based approach has developed in stages. It started from the 'behavioural objectives-movement' (Bowden and Marton, 1998; Melton, 1994), and progressed to 'mastery-learning' (Bloom, 1976), 'criterionreferenced' testing (Popham, 1978), 'minimum competency testing' (Jaeger and Tittle, 1980) to 'competency based education' (Burke et al., 1975). The main principles remain the same: a strong focus on outcomes, very relevant for the work-setting, outcomes are observable competences, assessments are judgements on competences and the accreditation issues ('improved articulation and credit transfer'). 
The competence concept has its roots far back in history (see Melton, 1994). In earlier times, competences had a lot in common with behavioural objectives. Behavioural objectives identity what individuals should ultimately be able to do. The main difference between behavioural objectives and competences is that the latter relate specifically to desired performance in the place of work while behavioural objectives are not confined to an occupational setting, and in fact more typically identify what candidates should be able to do to demonstrate their acquisition of knowledge and understanding in a more educational context.

The behavioural objective approach was integrated in teacher training programs in the U.S. and as the use of it increased, its weaknesses also became apparent. An important drawback of the behavioural objective approach is the so-called classification problem (or, as it is called in the behavioural objectives theory, the specificity problem) which relates to the fact that if you have a few general objectives, they are easy to handle, but too vague to be helpful in any policy. If on the other hand, the objectives are completely specified, the list may become very long. This led to the development of domain referenced objectives. These objectives consist of broad objectives and clarifying test items, which are meant to measure mastery. The main difference between domain referenced objectives and competences is that in the case of competences, the performance criteria and range statements identify the range of items that might be included in the domain, while in the case of domain referenced objectives, assessors use sampling techniques to assess performance.

Melton (1994) lists a number of limitations of the behavioural objectives methods and these can be transferred to highlight some of the problems inherent in much current research methods on competences. First, it should be remembered that measuring competences involves human judgement, and that it is not as scientific as one might hope for. Second, motivation plays a key role in achieving goals. Just measuring goals and performance without considering personal motivation is not enough. A third concern with competence measurement is that it often focuses on isolated rather then integrated skills. These integrated skills are much more complex and not only dependent on factors extracted from functional analysis. Fourth, the assessment of all aspects of competence is not practical; sampling techniques can make competence assessment more manageable. A fifth problem is that the present standards do little to help individuals to cope with changes in their work and work environment. Knowledge plays an important role in facilitating these changes. For example, it may help transfer competences from one context to another. Another way in which knowledge may help in change processes is that it can help people cope with change by providing them with a greater knowledge and understanding of the contexts in which their skills were originally developed and of other contexts in which they might be used. The sixth shortcoming of competence measurement is that it has largely focussed on training needs. Not enough attention has been given to the implications for higher education. Finally, competence assessment has often been designed to meet the needs of companies. It could, however, also be relevant to the needs of the individual, which is quite a different focus. 


\subsection{Competence Classifications}

In the literature on the classification of competences, the various perspectives on competences can be recognised as well. A well known classification from a labour market perspective is Becker's (1980) division between general and specific skills and training. Nordhaug (1993) argues that, although this distinction is relevant, it is not nuanced enough. In his book 'Human Capital in Organizations, Competence, Training, and Learning' he has extended this classification by combining the individual aspect of the competence concept with labour market productivity and organisational interests. He also recognises a difference in specific versus general training or competences in the issue of the match between people and work. He uses this difference for a classification of competences that is based on the theoretical notion of the difference between general and specific skills and training by Becker (1980). His division of competences is based on the usefulness of competences within specific contexts. He divides competences according to the specificity of use in tasks, firms and sectors of industry. The classification has been proposed for organisational research as well. Table 1 below gives an overview of how this approach leads to six different types of competences.

Table 1

Classification of competences according to Nordhaug (1993)

Firm specificity

Low High

Industry specificity

Low High

\begin{tabular}{clll}
\hline Low & $\begin{array}{l}\text { Meta- } \\
\text { Competences }\end{array}$ & $\begin{array}{l}\text { Industry } \\
\text { Competences }\end{array}$ & $\begin{array}{l}\text { Intra-Organizational } \\
\text { Competences }\end{array}$ \\
Task specificity & Standard & $\begin{array}{l}\text { Technical } \\
\text { Technical } \\
\text { High }\end{array}$ & $\begin{array}{l}\text { Trade } \\
\text { Competences }\end{array}$ \\
& Competences & Competences \\
\hline
\end{tabular}

For a detailed explanation of every type of competences and examples we refer to Nordhaug (1993). There are, however, two general features of this classification that we would like to mention. Firstly, the more dimensional idea of specificity; not only related to a work task, but also to a firm and an industry and, secondly: the proposition/premise of task specificity being related to technology in a material sense, based on the human capital research tradition originating from the industrial age.

The classification is unclear with respect to the possible existence of different combinations of the firm and industry dimension end-values. Furthermore, values somewhere on the continuum in specificity seem impossible, whereas in real working life, many nuances in job characteristics are possible. For some jobs competences such as communicating with 
people (clients) can be highly task specific, whereas for other jobs these competences are merely low task specific, for example for mechanics. Thus, highly task specific competences in work which encompass non-technological elements can be confused with other types of competences. This would be a serious shortcoming, since today's labour market is to be characterised merely knowledge based, instead of industry based (Petrella, 1997). A classification of competences that is taking this difference in object of jobs into account has been presented by Mulder (1997). She presents a theoretical distinction between different kinds of learning goals and qualifications for the purpose of designing an educational programme for entrepreneurs. Her classification is based on the theoretical insights into different other classifying literature on both competences and qualifications. She distinguishes 'learning goals', relevant for educational programmes, and 'qualifications', relevant for labour market functioning in terms of (competence) requirements. Both concepts can (only) be operationalized in terms of specificity for the working (or learning) context and the object of work; people, information or material. However, both concepts can be divided into a domain or context specific part and a part referring to handling dynamics. The socalled learning goals are merely described in cognitive terms and are divided into being domain specific or aimed at dynamic processes. The qualifications are merely related to (work) activities and are divided into context bound and handling the dynamic. Mulder explains that qualifications can be seen as activity-competences, but that competences are more abstract than qualifications and include what can be called the individual potential. Her classifying principle represents a one-dimensional continuum for both learning goals and qualifications. For learning goals the continuum goes from the domain specific cognitions to 'dynamic' cognitions (cognitive activities needed to obtain domain specific cognitions, as well as being able to use these in other domains and being able to monitor and direct ones' own cognitive functioning). For qualifications the continuum goes from the context bound to the 'dynamic' in terms of activities. Qualifications at the dynamic end of the continuum refer to transfer of knowledge and skills into new and different situations. The object of work (people, information, material) together with the specific working context, for which no classifying principle is given in this classification, determine the position on the continua for competences and the operationalisation in terms of learning goals or parts of qualifications.

Some general considerations should be noted here. In Mulder's research, competences are seen as individual potentials while, at the same time, learning goals in the educational context are still seen in terms of merely cognitive outcomes or functioning. The implies that other aspects of competence are not taken into account. On the other hand, however, the qualifications or competence requirements are stated in activity terms, which implies that the transition from education to work is only captured for the cognitive or knowledge component of competence, while the transition in activity terms remains a black box.

From the two examples of competence classifications, it has become clear that the educational perspective is quite different from the labour market perspective. There is however, a third relevant competence perspective: the HRM competence perspective. In the following section, measurement issues in these three perspectives will be discussed. 


\subsection{Competence Measurement Perspectives}

Today's literature about competence measurement can be roughly divided into three perspectives on the meaning of the concept: the educational perspective, the human resource management perspective and the labour market perspective. From all perspectives definitions are various and the distinction from other concepts such as 'skills' and 'qualifications' is not always clear. However, we try to summarise the main points from every perspective in the following sections.

\section{The Educational Perspective}

From the educational perspective, competences traditionally stem from the behavioural objectives movement (Melton, 1994) in which the objectives are generally operationalized as knowledge, skills and attitudes. But nowadays, competences are generally seen as composites of knowledge, skills and attitudes. This is referred to as the holistic perspective on the concept (Hager and Gillis, 1995; Straetmans, 1998). However, the operationalization of the term is in general quite analytical instead of holistic; still related to educational outcomes or performance criteria, which are static in nature.

The division into knowledge, skills and attitudes is recognised (within the educational perspective as well) to be an artificial simplification from an individual's working behaviour. Dynamic aspects can not be included in (educational) definitions of competence very easily. The dynamic aspect can be recognised, though, as a learning concept, because of the ongoing developmental process that is taking place during education and in work and the working context as well.

The recognition of 'learning behaviour' itself, instead of the traditional learning outcomes in terms of knowledge, skills and attitudes within education leads to an ongoing search for better definitions and operationalizations of 'competence' and 'competences' for this purpose. Recently Bowden and Marton (1998) have defined competences as (learning to) be(ing) able to handle a variety of perspectives on problems. They also make clear that this process requires disciplinary and professional knowledge, but possibilities of measurement of this process, or competences, are necessarily ambiguous. The question therefore is whether this more 'social' view on learning goals will be a realistic option for (formal) educational practice.

Current theory and practice favours the more referenced approach, in which performance criteria or otherwise clarifying indicators still determine the ultimate 'meaning' of competence (Straetmans, 1998). These criteria are now the educational targets, or desired outcomes that can be operationalized in terms of 'learning goals'. These standards are meant to be closely related to the requirements for labour market functioning. In this way we enter the second relevant perspective with respect to the meaning of 'competence': labour market research. 


\section{The Labour Market Perspective}

In economic labour market research, the concept of competence is often exchanged with 'skill' or 'qualification'. In fact, from the labour market perspective, it would be appropriate to use the term qualifications instead of competences, because of its origins. Competence stems from the learning- and cognitive theoretical science and it emphasises the individual perspective. Qualifications fit the research tradition with respect to job-analysis, and formal job requirements within the working context. It does not take the individual as a starting point. However, since work performance is not dependent on formal requirements alone, the concept of competence is sometimes more useful, considered from a labour market perspective (Hövels, 1998). Others argue that qualifications are more than formal requirements alone (Mulder, 1997) and that the term competence is not needed to replace the qualification concept. In applied research, either job characteristics or individual characteristics tend to be emphasized.

The term 'skill', on the other hand, is based on the idea of human capital theory, in which all productivity produced by people can be defined as 'skill'. This economic view does not bother with the exact meaning of the concept of 'skill', but just operationalises the economic issue of productivity. This may be measured in a variety of ways, ranging from very indirect by using proxies such as educational attainment to measuring as directly as possible, by applying self-reports to measure skills.

\section{The Human Resource management Perspective}

The concept of competence is also used extensively in the context of 'human resources'. This refers to the potential (behaviour) of people in their working environment and at the same time to the discipline that is specialised in the (use of) relevant knowledge with respect to this subject. It involves the total spectrum of human behaviour and its determinants in the organisational working context. The goal of human resource management is that of allocating competences in an optimal way and to solve problems with competence shortcomings.

In recent $\mathrm{HRM} / \mathrm{HRD}$ literature, the concept of competence is defined as integrated knowledge, skills and attitudes that can be used at work to perform, which means producing output in the direction of organisational goals (Dewulf, 1999). In this definition both a cognitive and a social view on learning are or should be present. This means that both the cognitive learning goals in terms of acquiring knowledge, skills and attitudes, as well as the more social learning goals in terms of agreement and mutual satisfaction are important for organisations. Starting point in most human resource development practice today is that competences are individually bound and can be developed (Klarus, Tillema, and Veenstra, 1999). This means the concept is by no means static, nor determined. The recognition of the mainly 'social' aspect of the definition of competences is the strength of the HRM/HRD perspective. This field is full of practitioners who have actually to work with peoples' competences, and then the more social, undetermined, meaning becomes fully apparent. 
Measurement methods that leave more room for subjective judgement on competences and mutual agreement are therefore much more accepted as valid measurement methods than in the other research fields. The so-called assessment centre techniques are a clear example of these.

\subsection{Competence Development}

In all perspectives, the issue of the development of competences is relevant as well. When the different perspectives on competences are seen as a whole this issue becomes particularly relevant, since competence development is then the clear link between the different perspectives (learning behaviour and learning style). Therefore, before turning to the measurement issues, we discuss competence development. Please note that this discussion should not be seen as a fourth competence perspective, but rather an element that is present in all three discussed perspectives.

The process of competence development can be seen from roughly two perspectives: from the perspective of the process of development itself, in terms of what happens with people when they develop competence, and from the perspective of the context for developing competence, in terms of in what kind of situations or through what channels people (can) develop competence. From the first perspective, mostly cognitive-psychological theoretical views have to offer relevant insights into the developmental process. From the second perspective, no specific research field has concentrated on this subject yet. However, from different fields and disciplines, we will highlight the main findings.

In cognitive-psychological research, the so-called expertise development studies have established the following insights with respect to acquiring knowledge and knowledge related expertise. The developmental process consists typically of three stages (Anderson, 1991; Proctor and Dutta, 1995). In the first stage a knowledge base has to be established. Small pieces of knowledge can be connected, but only in the second stage, sometimes referred to as the associative stage, different knowledge parts become connected in meaningful parts. The fragmentation of the first stage is left behind. In the third stage, also called the autonomous stage, proceduralisation of knowledge leads to complete 'scripts' (in case of medical knowledge) that can be triggered when one element of the knowledge base is activated.

In these stage models, people in the different stages of the development process are called novices, intermediates and experts, according to which developmental stage they are in. No less than ten years of practical experience are considered to be needed for an individual to become an expert (Proctor and Dutta, 1995; Vaatstra, 1996). These experts have the tendency to monitor their progress (in problem solving) more than novices, which refers to the use of meta-cognitive abilities and last, but not least: not everyone becomes an expert in his/her domain. Innate individual abilities are thought to play a role (Proctor and Dutta, 1995). 
In other (academic) learning models, such as the development stages of Perry (1970) the idea that not every student reaches the highest level of development within their level of education, is present as well. This fact has been taken into consideration in different learning models that emphasise the individual development of students and the factors affecting the cognitive learning process next to innate abilities.

In these models, the interplay between cognitive factors and other factors, such as affective factors and environmental factors are considered. One possibly interesting field of (educational) research in this respect is the integrative learning theory as proposed by Vermunt (1992). Vermetten (1999), following Vermunt (1992), is only hypothesising on the possible (if any) learning stages, but nevertheless the premises of the theory are interesting: a central role in learning has been ascribed to the so-called metacognitive regulation. This is defined as thinking activities aimed at regulating and controlling one's learning, e.g., orientation to and planning of one's learning process, and the monitoring of one's progress. The other parts of learning consist of cognitive processing activities, mental models of learning (conceptions), and learning orientations (motivation). The different parts of learning can be situated at three different behavioural levels: the regulation at the middle, the conceptions and motivation at the highest and the cognitive activities at the lowest level. The interaction between the levels is supposed to occur in a very complex way. Based on this, a conceptual model for student learning in higher education is presented. This model attributes a central role to the student's individual experience and perception in interaction with the environment (Vermetten, 1999). In this way, the ultimate learning determinants are all bound to the individual in the end. Nevertheless, the environmental influences, or situational factors, still play a role and until now it is to a large extent unclear what exactly can be ascribed to the individual and what to the environment.

In organisational research, the importance of individual characteristics for learning and development of competences is also emphasised; 'individual motivation and curiosity is probably more important in performing and developing competence than formal organisational strategies' (Kessels, 1999).

With respect to learning at work, Eraut et al. (1998) have used some theoretical notions of the social learning theory of Bandura (1986 and 1997) for analysing the learning processes at work. In short, learning is the interaction of individual characteristics, individual behaviour and environmental factors. The individual characteristics can be divided into trust, motivation and acquired capability. The environmental factors from Bandura's theory are divided into four categories, related to the micro-context in terms of how a person is managed (1), the (micro) culture of the workplace (2), and related to the macro-context in terms of the organisation (3) and professional bodies (4). Because the aim of the study was to describe how and what people learn at work, without any prior theoretical assumptions, the study lacks theoretical groundings. The study may, however, be helpful in establishing directions for theoretical bases that could underlay future research in the field of learning and work. This is also one of the explicit goals of the study, but the methodology, which consists of combining several theoretical notions, lacks the integration needed to reach this goal. 
Other attempts to understand the learning process or 'continuous career development' (London and Smither, 1999), or 'continuous professional development' (Presland, 1994) during work have led do different learning models based on several and various learning theoretical principles, but no one coherent theoretical framework is available yet.

Dewulf (1999) presents a working model for competence development from a practical human resource development perspective. This working model considers the process of development of competence from its original components (knowledge, skills and attitudes). These are learned in settings reaching from formal learning contexts such as school (class) settings ('off the job') to the further development during work ('on the job'). In the latter type of learning context, learning is merely informal, less structured, and influenced by different factors, intended and unintended. The eventual aim of this developmental process is seen as the realisation of organisational goals: output and performance.

The relation between the context of learning ('on the job' versus 'off the job') and the extent to which type of learning is (un)intentional has not been elaborated on in this working model. Instead, Dewulf (1999) simplifies matters, since 'on the job' is equated to 'informal' and 'unintentional', which implies a serious drawback of his model. However, on the positive side, at least some important factors of the developmental process, as well as the relation with learning routes have been incorporated in the model.

Recent ROA-publications consider the development of competences at the macro level. The process of (individual) development is not explicitly considered. Instead, changes that are taking place on the macro-level relationships between education and labour market outcomes are the issues under investigation. In this respect, the development from a rather static connection between education and work towards a more dynamic one, in which education and work are more integrated in terms of timing on the career path, is recognised. New models for optimising the relationship between education and labour market functioning (e.g. optimising learning routes) have to be developed (ROA, 1999).

\subsection{Summary: Problems in Competence Measurement}

The competence concept and therefore the issue of competence measurement have been subject to a lot of discussion and confusion. The main reason for this is that the measurement of competences can be studied from several viewpoints. These viewpoints are fairly divergent on competence definitions and competence classification. The review from the literature may be summarised in figure 1 below.

The figure presents a model, which gives an overview of the relations between competences, education and labour market outcomes. The basic idea of the model is that learning inputs such as initial education and the work setting lead to competence acquisition. Competences, in turn, lead to effects on the labour market, such as wage or a desirable position on the labour market. 
Figure 1

A model of inputs, competences and labour market outcomes

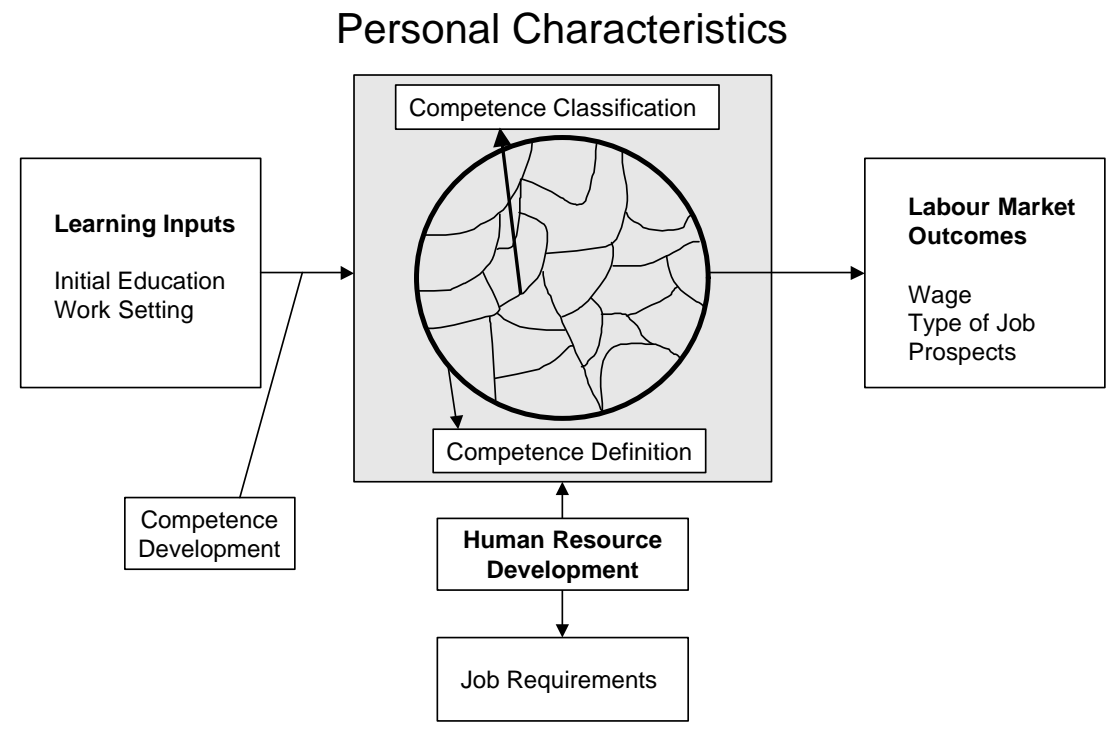

We may conclude that the review from the literature has shown that there are a number of different views on the competence concept. These differences have implications for competence measurement. Broadly speaking, we believe that there are three theoretical problems when competences are measured: the definition problem, the classification dilemma and the perspective problem. Note that these problems may be interrelated as well, and that next to the three theoretical problems, practical measurement problems (such as e.g. establishing a common reference criterium for all respondents) may exist as well.

The first problem that is encountered when trying to measure competences is the definition problem. This problem is concerned with the question of what individual characteristics can be considered competences and which characteristics are not competences. In figure 1, the definition problem is represented by the circle in the individual characteristics box. In this box, the grey area represents individual characteristics. The dots inside the circle are considered to be those characteristics that are part of an individual's competence base. The literature on competences reveals that there is not much agreement on what should be inside the competence circle.

The second problem in competence measurement is the classification dilemma. Once those characteristics that belong to the competence base have been selected, the problem is how to group these characteristics into a set of competences. This classification turns into a dilemma: one can either be completely specific about each element that constitutes a competence and end up with an endless list of items or one can try to group the characteristics in the competence base in such a way that a short list of competences results. Each individual competence in this list then becomes rather vague. A second 
problem that is part of the classification dilemma concerns the question of how to group characteristics together into a competence.

As can be seen from the literature, the competence concept is linked to education, the labour market and Human Resource Development (HRD). This implies that competences can be looked at from different perspectives. It is our contention that much of the confusion in the literature on competences arises due to the fact that different authors look at the competence concept from different perspectives: depending on the perspective different aspects of the concept are considered or emphasised as more or less relevant. This constitutes the third and final problem in competence measurement: the perspective problem.

\section{Competence Measurement in School-leaver Surveys}

Recently, there has been an increasing interest into the design of better ways to measure competences. But measuring competences is not an easy task. Depending on the definition chosen, the technique for competence measurement will differ substantially. In this section, we will focus on the possibilities for measuring competences in school-leaver surveys (3.1), discuss some recent contributions in the field of competence measurement research (3.2) and address some practical measurement issues (3.3).

Since contemporary research needs to go beyond disciplinary boundaries in order to solve current research problems in competence measurement, the exact meaning of 'skill' and 'qualifications' have appeared to become important in an individual sense as well (Sorenson, 1994). The competence concept is in this case representing what several labour market studies are interested in now. At the same time, educational research is aimed at integrating the new labour market requirements in its vocabulary, including the revised meaning of skill and qualifications. For organisational research the same development is visible; how to integrate educational or learning psychological theory into organisational behaviour analyses, and so on.

\subsection{Measurement Methodologies}

Spenner (1990) provides three ways to measure 'skills' in an economic context or from a labour market perspective. First, there is the non-measurement strategy, which simply assumes that some occupations are more 'skilled' then others. The second measurement method is the indirect measurement strategy. This is the way economists typically measure skills. They use proxies for competences, such as initial educational level, tenure, intensity of training courses, wages etc. The most reliable and valid approach to skill measurement is direct measurement, which implies empirical operations and explicit protocols for the designation of skill levels. There are two main ways to measure skills in a direct way. Firstly, it is possible to measures competences by using self-reports. This technique involves questions on the characteristics of the job, responsibilities and problems, the nature of the competence that is needed to do the job in a satisfactory way and the way of acquiring the 
competence (see Eraut et al., 1998). The other way is using expert ratings in skill measurement. These experts include outside observers, job analysts, researchers and key informants (such as e.g. managers). However, it is important to keep in mind that measurement of competences from a labour market perspective can concern various dimensions. Ellström (1998) mentions three views of competences. Competences can be considered attributes of individuals, job requirements or an interaction between the individual and the job ('competence-in-use'). In addition, in the first view, competences can mean the actually used competences in the job, or can refer to potential competences. Before measuring any kind of competence, it is extremely important to know what measure is actually being used.

Self-report competence studies in the US have often been based on the US Dictionary of Occupations (DOT). In the Netherlands, not that many studies exist that have skill measurement as their main focus. But whenever skills are investigated, there is always some link to the generally accepted national occupational classification. In surveys, often researchers try to capture dimensions of complexity and/or complexity of jobs. Of course, different studies have different set-ups, and one of the key differing aspects is the population under investigation. Some studies involve the whole of the labour force (e.g. Skills Survey in the UK by Green et al.) while other involve only a single occupation in a single company (e.g. the recent study by $\mathrm{ROA}$ on administrative employees in a large financial services company).

\subsection{Recent Competence Measurement Research, Some Examples}

In skills measurement research from a labour market perspective, Eraut et al. (1998) use self-reports to measure how people have acquired the competences they need in their work. The attention is focused on the nature of the job, recent tasks, responsibilities and problems, the characteristics of the competences that are needed to carry out the job in a satisfactory manner, and sources of learning.

Borghans et al. (2000) contains the findings of a pilot study that focused on the development of competences in a large company in the insurance industry. The study contains competence measures from a number of different perspectives. There are self-reports and expert (managers) measures that intend to measure potential competences, as well as job analysis components. The results might be helpful in further developing the theory behind competence acquisition and use.

The competence movement takes 'occupational standards' (clear and exact definitions of effective performance in a well-defined area of work) as one of its main fundamentals. Bowden and Marton (1998) believe that this is something that is impossible to accomplish. They adhere to a holistic approach to the competence concept where there is a three-way integration of someone's vision towards the professional role, the capacity to perform that role and the stock of knowledge that is tied to professional identity and performance. Measuring an outcome is very complicated in this framework, which at least partly explains why most competence theories do not reach such an 'outcome definition'. Therefore they 
propose a test-system which measures the capacity to judge situations and the capability to use more then one aspect of a problem simultaneously in problem handling, defining and solving in new contexts.

In order to measure these concepts reliably, the questions should be open and nontechnical, focused on phenomena, concepts and principles that are 'vital'. Comparing the answers to these questions enables judgement of them. In the context of ROA's large-scale school-leaver surveys, this methodology will not be very usable.

Straetmans (1998), in his memo on competence measurement, provides some practical guidelines: first, he states that the holistic competence concept is usually chosen in competence measurement (Hager and Gillis, 1995). This concept sees competences as combinations of knowledge, skills and attitudes that are required to deal with explicitly specified task-situations in an effective and efficient manner. Messick (1992), however, warns that competences are more then just simple additions of knowledge, skills and attitudes. Straetmans sees no problematic implications of this for measurement. A number of competence measures are subsequently discussed and attention is given to how test for the quality of measurement and how to improve measurement quality.

\subsection{Practical Measurement Problems}

In postal school-leaver surveys, the use of self-reports to measure competences is almost inevitable. This implies that for these surveys, the competence measurement methodology is already bound to self-reports of the individual respondents. There are, however, some general disadvantages of using self-reports for competence measurement. Firstly, respondents tend to overestimate their own level of skill (see also Arnold and Mackenzie Davey, 1992). Second, the ordering of questions can have serious effects on the scores on skill components. Spenner (1990), however, concludes that self reports offer relatively good prospects for skill measurement since their is no systematic evidence that people seriously distort reporting of their job characteristics. There are problems with wording, consistency in phrasing questionnaires, but these do not seem to be an impediment to self-report skill research. Although this argument is not completely theoretically sufficient, it at least provides some rationale to use self-reports for competence measurement.

Other practical problems in competence measurement in the context of school-leaver surveys is that researchers have to select a list of competences that is relevant for all occupations and educational backgrounds and that this list should not be too long in order to avoid that the questionnaire becomes too much of a burden for respondents. In addition, in order to compare respondents with different educational and occupational backgrounds, the list of competences would ideally provide a common reference criterion for all respondents. Finally, one has to select what should be measured: Job characteristics, the use of competences, or the competences as individual potentials. These and other practical issues in the design of competence measurement strategies in ROA's school-leaver surveys will be elaborated on in the next section. 


\section{Measuring Competences in ROA's School-leaver Surveys}

School-leaver research in the Netherlands has been carried out for a number of years within the Research Centre for Education and the Labour Market (ROA). The broad objective of the project is to investigate the position of school-leavers. Therefore, many items in the survey are meant to get a clear view of this position. Since the ROA-surveys cover a large part of the educational system, it is possible to calculate 'rate of returns' for different types and levels of education. Attention has also been given to provide information on competences that were learned in a satisfactory way during school and those items that have not been adequately addressed in education. This has been used as a policy instrument for determining if more attention is needed in some area of expertise.

The list of competences that has been surveyed until 1998 in the surveys does not have a strong theoretical foundation. It has been started as a list of around 20 items and throughout the years, items have been added, partly because of demands by commissioners of the project, partly because of scientific interest. The disadvantage of this development has been that the competence list consisted of 29 items and the competence block in the questionnaire has become quite a burden for the respondents.

Another concern with the competence part in the ROA-surveys has been that the variability of the answers is fairly low. A large proportion of the respondents chose to select the higher answer categories in the Likert-scaled questions. We believe this has two main causes:

- the list of competence items is too long;

- the formulation of the questions has probably not been optimal.

In order to deal with these problems, we have started by first defining the competence concept properly. For school-leavers, we define competences as

\section{Composites of individual attributes that represent context-bound productivity}

This definition contains three important elements: Firstly, competences are composites of attributes, which implies that we define them as being holistic. Secondly, competences represent productivity, which clearly indicates that we define them from a labour market perspective. And finally, competences are context bound, which implies that we define them in the context of the situational characteristics (i.e. job or educational background). The link with productivity in the definition has led us to measure the use of competences, since unused potentials are unlikely to have direct productivity effects. For research on the gaps between actual use of competences and competence potentials, it would be preferable to measure competence potentials as well. In the context of postal school-leaver surveys, however, this poses even greater measurement problems, since research indicates that respondents in general tend to distort the answers to competence potential questions in asymmetric ways: Borghans et al. (2000) report, for instance, that respondents tend to be relatively honest when it concerns easily quantifiable aspects of competence potentials, but tend to overestimate their potential when it concerns the less quantifiable competences (the 
'softer' skills). These substantial practical measurement problems concerned with competence potentials has led us into adopting a measurement strategy that is only based on the use of competences.

For competence measurement in school-leaver surveys the chosen definition has several implications. The classic division of competences into skills, knowledge and attitudes has been abandoned. The new measurement methodology introduced in 1999 features less competence items and a new phrasing of the questions. Table 2 gives an overview of the changes that have taken place. Appendix A contains the relevant questions of the 1998 and 1999 surveys.

The formulation of the competence questions in the survey until 1998 has been strongly in terms of job characteristics, while the new questions try to determine the respondent's characteristics. We tried to separate the use of competences from the level of required mastery and also asked where respondents have mainly acquired the competences ('source of learning'). Using the 'use' ('competence-in-use') phrasing, the competence concept is measured in a holistic sense, since effectively using a competence implies using all the classical competence 'ingredients': Skills, knowledge and attitudes.

Table 2

Competence measurement methodologies compared

\section{Comparable competence items*}

Professional theoretical knowledge

Professional methods and techniques

Understanding of ICT (incl. computer use)

Planning, coordinating and organising activities

Leadership skills

Co-operationg, working in a team

Independence

Adaptability

Accuracy, carefulness

Quantitative (research) skills (being able to work with figures)

Written presentation, writing skills

Oral presentation, speaking skills

Negociative and commercial skills

Initiative, creativity

\section{Non-comparable competence items}

Analytical and diagnostic (research) skills

Foreign language skills (active and passive command)

Functioning under work pressure

Loyalty, integrity, dealing with opposing interests
Professional theoretical knowledge

Professional methods and techniques

Computer use

Planning and organising

Leadership skills

Working in a team

Independence

Dealing with changes

Accuracy

Dealing with numbers

Communication skills

Initiative

Creativity 
Table 2 (continued)

Competence measurement methodologies compared

Systematic reflection, feedback

Contactual skills

Pedagogic-didactic skills (including instruction and transfer of

knowledge)

Problem-solving skills

Gathering and documenting information, data management

Qualitative (research) skills

Recognising policy implications from research results

Recent developments and trends in professional field

Understanding of legal regulations in field (incl labour regulations)

Understanding of operational management (organisational, financial, administrative)

Putting (theoretical) knowledge and techniques into practice

\section{Formulation in surveys}

International orientation

Importance of Competences in job (Likert 1-5)

Use of competences (Likert 1-5)

Required level of mastery (Likert 1-3)

More/equal/less attention in education required?

Top3 of competences sufficiently and insufficiently attended in education

Most important learning source (school/work/else)

\footnotetext{
* The comparable items may not always be completely comparable, since 1) the wording of some competence items has changed slightly and 2) the general formulation of the survey questions has been revised.
}

In addition, we have tried to establish a trade-off for the 'Attention' questions. In 1998, for each competence, respondents were asked whether they found that their education had paid enough, too little, or too much attention to the competence involved. This led to answers with very little variation and since the wording of the question did not present respondents with a trade-off between competence items, almost all respondents answered that the same or more attention should be payed to all competences. This clearly does not present policy makers with a trade-off, e.g. that more attention should be paid to ICT skills, while loyalty should be less focused on in education. Therefore, in 1999, respondents were asked to complete a 'Top3' of competences sufficiently and insufficiently attended in education.

This measurement methodology is actually a combination of three of the discussed competence perspectives. Firstly, the labour market perspective is addressed by the 'competence-in-use' concept in the 'use' questions. These questions permit the investigation of the relation between the competences actually used and indicators for labour market success (e.g. the wage). 
In addition, the level of required mastery tries to incorporate a level-measure in the competence concept, enabling research into the effects of mastery of certain skills. Secondly, the process of competence development is addressed by the questions on the most important learning source. Thirdly, the evaluation of competences insufficiently and sufficiently attended in education can be considered competence measurement from an educational perspective.

\section{Empirical results from comparing two competence measurement methodologies}

In order to get a general impression of the difference between the two methodologies, we first present some summary measures for the effectiveness of the questionnaires in both 1998 and 1999 in section 5.1 and 5.2. Next, we will investigate the effectiveness of both competence methodologies in terms of the prediction of wages, both for the group of schoolleavers as a whole (section 5.3), as well as for a number of selected educational and occupational categories (section 5.4). The empirical results in these sections will be based on the school-leaver data for both Higher Vocational Education (HVE) and University Education (UE) graduates from several schools and universities in the Netherlands.

\section{1 'Importance' vs 'Use' methodology}

In table 3, we compare the 'importance' (1998) to the 'use' (1999) methodologies. For more detailed information on the correlations, please refer to appendix $B$ of this paper.

Table 3

Summary measures for the efficiency of questionnaires 1998 and 1999, 'Importance' vs 'Use'

\begin{tabular}{lrr}
\hline Indicator & $1998(\mathrm{n}=11471)$ & $1999(\mathrm{n}=10522)$ \\
\hline & 'Importance' & 29 \\
Used competence criterion & 29 & 14 \\
Number of competences & 0.22 & 0.17 \\
Average correlation between items & $14 / 29(48 \%)$ & $1 / 14(7 \%)$ \\
Correlation coefficients $>0.5$ & $2.16 \%$ & $1.61 \%$ \\
Average of system missing responses & & \\
\hline
\end{tabular}

The approximate halving of the number of competences causes the average correlation between the items to decrease by about $5 \%$-points. This, however cannot be considered direct evidence of a better 'separation of competences', since the shortening of the competence list itself is expected to have a decreasing effect on the average correlation regardless of any improvements in measurement methodology. However, when we look at the percentage share of correlation coefficients that are $>0.5$, the decrease is so dramatic (the reduction in competence items causes a move in this share from $48 \%$ to $7 \%$ ) that it would be hard to believe that a better separation of competences is not achieved. Another 
expected result concerns the percentage of system missing values. We observe that the reduction in competence items reduces the average \% of system missing responses by about $0.6 \%$. In relative terms this implies a reduction of system missing values of about $25 \%$.

\section{2 'Attention' vs 'Top3' methodology}

Table 4 compares the 'Attention' (1998) to the 'Top3' (1999) methodologies. In order to make the scores comparable, we had to perform a calculation with the top3 list to make both methodologies comparable.

Table 4

Summary measures for the efficiency of questionnaires 1998 and 1999, 'Attention' vs 'Top3'

Indicator

$1998(n=11721)$

$1999(n=10682)$

Used competence criterion

Number of competences

'Attention'

29

4.4

3.2 *
'Top3'

14

8.9

15.9 *

Average $\%$ of system missing responses

1998 and 1999, the system missing Due to the differences in the set-up
responses are not directly comparable

The table shows that the spread in answers has more then doubled. This implies that the new set-up of the questionnaire has clearly improved the variability of the answers.

\subsection{Survey efficiency in terms of wage prediction: the group of school-leavers as a whole}

From a labour market perspective, competences are expected to have an effect on labour market outcomes. Human capital theory sees competences as indicators for productivity and according to this theory, productivity should be reflected to some extent in wages. In order to rate the two methodologies in terms of prediction of the wage, we have performed a number of wage regressions, where the log of wages is related to the competence measures and a number of background variables. To be precise, we have estimated the following model:

$$
\ln W_{i}=\beta_{0}+\beta_{1} C_{1 i}+\ldots+\beta_{n} C L_{n i}+\beta_{/ 1} C L_{1 i}+\ldots+\beta_{\ln } C L_{n i}+\beta_{g} G E N D E R_{i}+\beta_{a} A G E_{i}+\beta_{e} E T H N I C_{i}+\varepsilon_{i}
$$

where the C's are the use (1999) or importance (1998) of competences; the CL's are the level of mastery required for each competence. Note that these latter variables are not available for the 1998 measurement methodology; they are therefore excluded from the 1998 estimation. The $\beta$ 's are the wage premia for the use (and the level) of competences. Positive wage premia are easy to interpret, they are rewards for the use of certain competences. Negative wage premia are, however, harder to explain. These will probably occur with competences that are considered attributes of low-level (and low paid) jobs. In 
addition to the competence variables, we have included three background variables: Gender, age and ethnicity. Gender has been included to take account of male-female wage differences. Age is often considered a proxy for experience, and may, when not all experience is reflected in the competence variables, have a positive effect on wages. In order to take account of possible discrimination effects of ethnic minorities, we have included the ethnicity dummy variable (ETHNIC). A comparison of the efficiency of the competence measurement methodologies and a general impression on the way differences in competences explain differences in wages may be obtained by estimating competencewage equations. We have therefore estimated two (log) wage equations for 1998 and six (log) wage equations for 1999. In table 5, we present the R-squared measures for each of these regressions. We find that the 29 competence questionnaire in 1998 scores worse in terms of r-squared than the 14-items 1999 'use' measure questionnaire. The R-squared is also higher for 1999, when only competences that are comparable in both survey years are included in the wage equation.

Table 5

$R$-squared measures for competences-wage regressions (entire sample, HVE and UE graduates)

Equation

R-squared

1998

29 competences, 'importance'

0.23

12 competences, 'importance' comparable to 1999 questionnaire $\quad 0.20$

1999

14 competences, 'use' measure

0.27

14 competences, 'level' measure

0.26

14 competences, 'excellent' dummy measure

0.23

14 competences, 'use' and 'excellent' dummy measure

0.27

12 competences, comparable to 1998, 'use' measure

0.26

12 competences, comparable to 1998 , 'excellent' dummy measure

12 competences, comparable to 1998, 'use' and 'excellent' measure

0.27

In table 6 we present two competence-wage equations; one for the 1998 'importance' measurement methodology and one for the 1999 'use' methodology. In these wage equations only the comparable items of both methodologies are included.

In terms of predicting wages, the 1999 methodology seems to perform better. Of the 12 competences included in the estimation, 10 are significantly different from zero. Using the 1998 methodology, only 5 of the 12 competences have a significant wage effect. Age and gender have the expected effects, while the ethnic background does not seem to matter for wages. Since differences in the graduates samples of 1998 and 1999 with respect to field of study and type of job may affect the results, we report our findings of the analyses carried out for different types of educational backgrounds and occupations in the next section. 
Table 6

Predicting wages using the 1998 and 1999 competence measurement methodologies

\begin{tabular}{lcc}
\hline & $\begin{array}{c}1998 \\
\text { Parameter }\end{array}$ & $\begin{array}{c}1999 \\
\text { Parameter }\end{array}$ \\
\hline Communication skills & $0.01621^{*}$ & $0.01238^{*}$ \\
Leadership skills & $0.01823^{*}$ & $0.01935^{*}$ \\
Accuracy & -0.03077 & $-0.01935^{*}$ \\
Information and communication technology skills & -0.00053 & $0.006498^{*}$ \\
Planning, co-ordinating and organisation of activities & 0.005093 & $0.01386^{*}$ \\
Dealing with numbers & $-0.00474^{*}$ & $0.007072^{*}$ \\
Teamwork & 0.00327 & 0.001128 \\
Capacity to deal with changes & $0.0012766^{*}$ & $0.01396^{*}$ \\
Specialised professional knowledge & 0.00332 & $0.01083^{*}$ \\
Subject-specific methods and techniques & -0.00077 & 0.0007308 \\
Capacity for independent work & $0.01618^{\star}$ & $0.01022^{*}$ \\
Creativity and initiative & -0.00083 & $-0.008918^{*}$ \\
Constant & 7.426 & 7.500 \\
Gender & $-0.08638^{*}$ & $-0.0947^{*}$ \\
Age & $0.02826^{*}$ & $0.02485^{*}$ \\
Ethnic Background & 0.002482 & -0.0009617 \\
R-squared & 0.20 & 0.26 \\
N & 9873 & 9255 \\
\hline
\end{tabular}

${ }^{*}=$ significantly different from zero at a $5 \%$ or better level of confidence.

\subsection{Differentiating by Type of Education and Occupation}

The results obtained for the entire sample of Higher Vocational Education and University Education give a general indication of which competences matter for wages. However, this approach does not take into account the differences that exist between types of education and occupations. For different segments on the labour market, different competences may matter, and therefore we have carried out estimations for a number of educational backgrounds and types of occupations. Since our purpose was not to compare occupations or educational backgrounds, but rather to compare the efficiency of wage prediction in the two survey years, we have chosen a number of large segments in the educational spectrum, in order to be able to obtain reliable results. We report the results of those estimations in this section. First we present the competence-wage equations for 4 different types of education in higher vocational education and 7 types in university education. The results are in table 7 below.

In the table, the regression results appear in a very abbreviated manner. In parentheses, the number of positive competence coefficients, the number of negative competence coefficients and the R-squared measure are presented for each type of educational category and for three competence methodologies: the 1998 'importance' questions, the 1999 'use' questions and the 1999 'use' and 'level' questions. We find that for most types of education, the 1999 methodology performs better in terms of R-squared than the 1998 methodology. We also find that for a number of educational backgrounds, the number of significant competence 
coefficients increases, while for others, we actually find a decrease of significant parameters. The new competence measurement methodology introduced in 1999 seems to work best for those school-leavers with an economic education. Looking at the last column in the table, we find that the level of required mastery seems to be more important for the graduates with higher vocational education. In the field of university education, only for the behavioural sciences the level of required mastery plays a role in explaining the wage.

Table 7

Short competence-wage regression results for levels and types of education

\begin{tabular}{llll}
\hline Type of Education & 1998 & 1999 & 1999 \\
& 'Importance’* & 'Use'* & 'Use and Level** \\
\hline
\end{tabular}

Higher Vocational Education

Technical

Economical

Medical

Behavioural

University Education

Technical

Economical

Medical

Behavioural

Art

Law

Natural Sciences

$\begin{array}{ll}(4+, 1-, 0.208) & (3+, 1-, 0.269) \\ (2+, 1-, 0.173) & (6+, 1-, 0.327) \\ (0+, 0-, 0.323) & (1+, 2-, 0.278) \\ (2+, 1-, 0.286) & (3+, 1-, 0.403)\end{array}$

(3+,1-, L3+,LO-,0.278)

$(5+, 1-, \mathrm{L} 4+, \mathrm{L} 1-, 0.332)$

$(1+, 2-, \mathrm{L} 1+, \mathrm{LO}-, 0.296)$

$(3+, 1-, \mathrm{L} 1+, \mathrm{LO}-, 0.409)$

\footnotetext{
* In between parentheses are (Number of significant positive competence use coefficients, number of significant negative competence use coefficients, R-squared).

** In between parentheses are (Number of significant positive competence use coefficients, number of significant negative competence use coefficients, number of significant positive competence level coefficients, number of significant negative competence level coefficients, R-squared).
}

In table 8, we perform regression analyses for different occupations. For occupations in the group of workers with Higher Vocational Education, the regression results for 1999 are all better than the results for 1998, when we compare the estimates in terms of R-squared. This result is most pronounced for the associate accountants. For occupations in the University Education domain, this is not the case.

The results reveal that the explanatory power of the regressions for the subgroups, grouped by type of education of occupation is better than the overall regression results for the group of school-leavers as a whole. This indicates that the measurement methodology chosen might not be completely optimal yet, in the sense that for different segments on the labour market, the competence items mean different things. This also proves that one of the key issues in future research on the measurement of school-leaver competences should be the development of a common reference criterion for competences. However, the results also show that for most segments on the labour market, the explanatory power of the wageregressions increase, indicating that the new measurement methodology at least performs 
better than the methodology previously used. Whether the improvements are due to the new formulation of the competence questions, the shorter list of competences, or a combination of both, is hard to determine, since this would require a more experimental research set-up.

Table 8

Short competence-wage regression results for levels and types of occupation

Type of Educational Level and Occupation $\begin{gathered}1998 \\ \text { 'Importance'* }\end{gathered} \begin{gathered}1999 \\ \text { 'Use'* }\end{gathered} \quad \begin{gathered}1999 \\ \text { 'Use and Level** }\end{gathered}$

Higher Vocational Education

$\begin{array}{llll}\text { Organisational advisors } & (1+, 1-, 0.362) & (2+, 1-, 0.551) & (3+, 1-, \mathrm{L} 1+, \mathrm{L} 0-, 0.583) \\ \text { Socio-cultural occupations } & (0+, 0-, 0.213) & (0+, 1-, 0.357) & (0+, 1-, \mathrm{L} 0+, \mathrm{L} 1-, 0.374) \\ \text { System analysts } & (1+, 1-, 0.176) & (2+, 0-, 0.326) & (1+, 1-, \mathrm{L} 2+, \mathrm{L} 1-, 0.367) \\ \text { Associate accountants } & (0+, 0-, 0.087) & (4+, 2-, 0.397) & (4+, 1-, \mathrm{L} 1+, \mathrm{L} 0-, 0.409) \\ \text { Commercial occupations } & (0+, 1-, 0.240) & (2+, 1-, 0.271) & (1+, 1-, \mathrm{L} 1+, \mathrm{LO}-, 0.287) \\ \text { University Education } & & & \\ \text { Legal occupations } & & & \\ \text { Medical occupations } & & & \\ \text { Commercial occupations } & (2+, 0-, 0.445) & (0+, 1-, 0.382) & (0+, 1-, \mathrm{L} 1+, \mathrm{L} 1-, 0.436) \\ \text { Economists } & (2+, 0-, 0.267) & (2+, 1-, 0.378) & (2+, 1-, \mathrm{L} 0+, \mathrm{L} 0-, 0.400) \\ \text { Civil engineers } & (0+, 0-, 0.255) & (0+, 0-, 0.229) & (0+, 0-, \mathrm{L} 0+, \mathrm{L} 0-, 0.364) \\ & (2+, 0-, 0.323) & (1+, 1-, 0.315) & (1+, 2-, \mathrm{L} 1+, \mathrm{L} 0-, 0.374) \\ & (1+, 1-, 0.207) & (2+, 1-, 0.178) & (0+, 0-, \mathrm{L} 2+, \mathrm{L} 2-, 0.304)\end{array}$

\begin{abstract}
* In between parentheses are (Number of significant positive competence use coefficients, number of significant negative competence use coefficients, R-squared).

** In between parentheses are (Number of significant positive competence use coefficients, number of significant negative competence use coefficients, number of significant positive competence level coefficients, number of significant negative competence level coefficients, R-squared).
\end{abstract}

\title{
6 Conclusions and considerations for further research
}

The measurement of competences has been subject to a lot of discussion and confusion. Designing a competence measurement strategy requires, in our view, a sound understanding of the competence concept itself. Therefore we have reviewed the literature on competences and competence measurement in section 2 . The literature reveals that next to practical measurement issues, three theoretical measurement problems play a role in the field of competence measurement. Firstly, there is a definition problem, which refers to the fact that competences can be defined in many different ways. Secondly, there is a classification dilemma: how to group personal characteristics into a set of competences. The third problem in competence measurement is the perspective problem. Since competences have been addressed and analysed in various disciplines, there are a number of different ways to look at the concept. In this paper, we have reviewed the literature from the educational perspective, the labour market perspective, and the human resource management (HRD) perspective.

In the second part of the paper, we move from theoretical insights from the literature to the practical issue of competence measurement. We have reviewed a number of recent 
contributions in this field and have, based on the empirical problems associated with previous survey years, developed a new competence measurement methodology. This developmental process has started by the choice of an explicit working definition of competences in the context of school-leaver research. Working with this definition and the theoretical insights obtained resulted in the competence measurement methodology we have adopted in ROA's 1999 school-leaver survey. It differs from the methodology used prior to 1999, in the sense that a holistic concept of competence has been adopted and that the phrasing of the questions is tailored to measure individual and not job characteristics. However, the specific content of the competence items may still not be optimal and will be subject to continuing research. In addition, applying the 'use' criterion prevents us from measuring competences in the sense of individual potentials. Measuring potentials may, however, present even greater measurement problems.

A first step in evaluating the new competence items is made in the final part of the paper, where we have attempted to compare the 'importance' (1998) and 'use' (1999) competence measurement methodologies in terms of efficiency by comparing empirical results from the two surveys. The efficiency of the questionnaires is addressed from three perspectives: the general efficiency of the questions in terms of missing values, the explanatory power of competences in wage regressions for the entire sample and the explanatory power of competences in labour market segment specific wage regressions. We find that, overall, the new competence measurement methodology seems to perform better in terms of missing values and explanatory power in wage regressions for the total sample of school-leavers. When we estimate competence-wage regressions for different educational backgrounds and occupations, we find that for some educational segments, the new competence measurement methodology works better, while for others, the previous methodology leads to better results. This is somewhat puzzling, but it indicates that competences mean different things for respondents in the different labour market segments. This implies that we have not yet been able to design a measurement methodology which features 'common reference" competences.

Overall, we may conclude that although we have extensively studied competence measurement in the field of school-leaver surveys in this paper, our quest for a superior measurement methodology is not over yet. We are not yet able to scientifically justify our choice for a specific list of competences, implying that although we have identified the definition problem and the classification dilemma, we have not yet solved them. In addition, in our view, the measurement of competences in the sense of individual potentials has not yet been realised. In the context of school-leaver surveys, this remains a problematic issue which will remain on our research agenda. On the positive side, however, the empirical evidence suggests that the new measurement methodology adopted in the 1999 survey, which is based on the 'competence-in-use'-concept, performs better than the methodology previously used. 


\section{References}

Anderson, J. (1991), Cognitive Psychology and its Implications: W.H. Freeman and Company.

Arnold, J., and K. Mackenzie Davey, (1992), Self-Ratings and Supervisor Ratings of Graduate Employees' Competences During Early Career. Journal of Occupational and Organizational Psychology, 65, pp. 235-250.

Bandura, A. (1986), Social foundations of thought and action : a social cognitive theory. Englewood Cliffs, N.J.: Prentice-Hall.

Bandura, A. (1997), Social learning theory. Englewood Cliffs ; London: Prentice-Hall.

Becker, G. S. (1980), Human Capital, a Theoretical and Empirical Analysis, with Special Reference to Education. (2 ed.): The University of Chicago Press, Chicago/London.

Bloom, B. S. (1976), Human Characteristics and School Learning, McGraw-Hill, New York.

Borghans, L., J. van Loo, E. de Ruyter, M. De Steur, J. Sanders and J.D. Vlasblom (2000), Organisatieveranderingen en Competentie-ontwikkeling, Verslag van een Enquête bij Het Kantoor (ROA-R-2000/3), Maastricht.

Bowden, J., and F. Marton (1998), The University of Learning, Beyond Quality and Competence. Kogan Page, Göteborg.

Burke, J. B., J. H. Hansen, W. R. Houston and C. Johnson (1975), Criteria for Describing and Assessing Compentency Programmes. Syracuse, National Consortium of Competency Based Education Centres, New York.

Carr, D. (1993), Questions of Competence. British Journal of Educational Studies, 41(3), pp. 253-271.

Dewulf, L. (1999), Ontwikkelen van Competenties. Opleiding en Ontwikkeling, 12(1/2), pp. 23-27.

Ellström, P. (1998), The Many Meanings of Occupational Competence and Qualification: in W. J. Nijhof and J. N. Streumer (Eds.), Key Qualifications in Work and Education, Kluwer Academic Publishers, pp. 39-50.

Eraut, M., J. Alderton, G. Cole, and P. Senker (1998), Development of Knowledge and Skills in Employment (Research Report Series 5), University of Sussex Institute of Education, Brighton.

Glaser, R. (1990), The Reemergence of Learning Theory Withing Instructional Research, American Psychologist, 45(1), pp. 29-39.

Green, F. (1998), The Value of Skills .

Green, F. (1999), The Value of Skills .

Hager, P., and S. Gillis (1995), Assesment at Higher Levels: in W.C. Hall (Ed.), Key Aspects of Competency Based Assessment, National Centre for Vocational Education Research Ltd, Adelaide.

Hall, D.T. and J.E. Moss (1998), The New Protean Career Contract: Helping Organizations and Employees Adapt, Industrial Relations, 26(3), pp. 22-37.

Hövels, B. (1998), Qualification and labour markets: institutionalisation and individualisation: in W.J. Nijhof and J.N. Streumer (Eds.), Key Qualifications in Work and Education, Kluwer Academic Publishers, pp. 51-62.

Jaeger, R. M., and Tittle, C. K. (Eds.). (1980), Minimum Competency Achievement Testing: Motives, Models, Measures, and Consequences. Washington, D.C.: American Educational Research Association.

Klarus, R., H.H. Tillema, and J. Veenstra (1999), Beoordelen: met competentieprofielen of kwalificatiestructuren: Onderwijs en bedrijfsleven staan weliswaar nog ver van elkaar af in de wijze waarop zij beoordelen, maar groeien meer en meer naar elkaar toe in denken over en kiezen van de wijze van beoordeling van medewerkers. Opleiding and ontwikkeling, 12(11), pp. 15-26.

London, M., and J. Smither (1999), Career-Related Continuous Learning: Defining the Construct and Mapping the Process. Research in Personnel and Human Resources Management, 17, pp. 81121. 
Melton, R.F. (1994), Competences in Perspective. Educational Research, 36(3), pp. 285-294.

Messick, S. (1992), The Interplay of Evidence and Consequenses in the Validation of Performance Assessments . Princeton NJ: ETS.

Mulder, R. (1997), Leren Ondernemen, Ontwerpen van Praktijkleersituaties voor het Beroepsonderwijs. , EUR, Rotterdam.

Nordhaug, O. (1993), Human Capital in Organizations, Competence, Training, and Learning, Oxford University Press, Bergen.

Perry, W. (1970), Forms of Intellectual and Ethical Development in the College Years- A Scheme, Holt, Rinehart and Winston, New York.

Petrella, R. (1997), The Snares of the Market Economy for Future Training Policy: Beyond the Heralding There is a Need for Denunciation. Adult Education and Development, 48, pp. 19-33.

Popham, W. J. (1978), Well-Crafted Criterion-Referenced Tests. Educational Leadership, 36(2), pp. 91-95.

Presland, J. (1994), Learning Styles and CPD. Educational Psychology in Practice, 10(3), pp. 179184.

Proctor, R. and A. Dutta (1995), Skill Acquisition and Human Performance, Vol. 1, Thousand Oaks: Sage Publications.

Researchcentrum voor Onderwijs en Arbeidsmarkt (1999), De Arbeidsmarkt naar Opleiding en Beroep tot 2004 (ROA-R-1999/8), Maastricht.

Sorenson, A. (1994), Opportunity and Training Effects on Career : Network on Transitions in Youth.

Spenner, K. I. (1990), Skill: Meanings, Methods and Measures. Work and Occupations, 17(4), pp. 399-421.

Stevenson, J. (1996), The Metamorphosis of the Construction of Competence. Studies in Continuing Education, 18(1), pp. 24-42.

Straetmans, G. (1998), Toetsing van Competenties (Puclicaties Voortgezet Onderwijs ), CITO, Arnhem.

Vaatstra, R. (1996), Expertise in Accountancy, UM, Maastricht.

Vermetten, Y. (1999), Consistency and Variability of Student Learning in Higher Education, KUB, Tilburg.

Vermunt, J. (1992), Leerstijlen en Sturen van Leerprocessen in het Hoger Onderwijs, Naar procesgerichte Instructie in Zelfstandig Denken, Swets and Zeitlinger, Amsterdam. 


\section{Appendix A: Competence items in the 1998 and 1999 surveys}

\section{Competence items in the 1998 questionnaire}

$\mathrm{Q}$ : The aspects listed below could affect the way you carry out your current job. Answer both parts of the question for each aspect, circling the number which best describes your opinion.

\section{a. Importance}

How important is the listed aspect for carrying out your job properly?

\section{b. Attention}

Should more, as much or less attention be paid to the aspect listed than was the case during your university study?

\section{a.Importance b.Attention}

Not Lery Less equal more
Important

\section{Aspects}

\section{Knowledge and techniques}

Professional theoretical knowledge

Professional methods and techniques

Recent developments and trends in professional field

Understanding of ICT (incl. computer use)

Understanding of legal regulations in field (incl. labour regula ${ }^{\text {os }}$ ) 1

Understanding of operational management (organisatorial,

financial, administrative)

\section{General skills}

Putting (theoretical) knowledge and techniques into practice Analytical and diagnostic (research) skills

Quantitative (research) skills (being able to work with figures)

Qualitative (research) skills)

Recognising policy implications from research results

Foreign language skills (active and passive command)

Written presentation, writing skills

Oral presentation, speaking skills

Negotiative and commercial skills

Planning, co-ordinating and organizing activities

Gathering and documenting information, data management

Leadership skills

Pedagogic-didactic skills (instruction and transfer of knowledge) 1

Problem-solving skills

Contactual skills

Co-operating; working in a team

$\begin{array}{lllllll}2 & 3 & 4 & 5 & 1 & 2 & 3 \\ 2 & 3 & 4 & 5 & 1 & 2 & 3 \\ 2 & 3 & 4 & 5 & 1 & 2 & 3 \\ 2 & 3 & 4 & 5 & 1 & 2 & 3 \\ 2 & 3 & 4 & 5 & 1 & 2 & 3 \\ 2 & 3 & 4 & 5 & 1 & 2 & 3\end{array}$
3 


\section{Attitudinal aspects}

23. Independence

24. Initiative, creativity

25. Adaptability

26. Functioning under work pressure

27. Accuracy, carefulness

28. Loyalty, integrity, dealing with opposing interests

29. Systematic reflection, feedback

$\begin{array}{llllllll}1 & 2 & 3 & 4 & 5 & 1 & 2 & 3 \\ 1 & 2 & 3 & 4 & 5 & 1 & 2 & 3 \\ 1 & 2 & 3 & 4 & 5 & 1 & 2 & 3 \\ 1 & 2 & 3 & 4 & 5 & 1 & 2 & 3 \\ 1 & 2 & 3 & 4 & 5 & 1 & 2 & 3 \\ 1 & 2 & 3 & 4 & 5 & 1 & 2 & 3 \\ 1 & 2 & 3 & 4 & 5 & 1 & 2 & 3\end{array}$




\section{Competence items in the 1999 questionnaire}

Q1: The aspects listed below could affect the way you carry out your current job. Answer the three questions for each aspect, circling the number which best describes your opinion.

\section{a. Use}

To what degree do you use the listed aspect in your work?

\section{b. Required level of mastery}

How well do you need to master the listed aspect?

\section{c. Where primarily learned}

Where have you primarily learned the listed aspect?

\begin{tabular}{|c|c|c|c|c|c|c|c|c|c|c|c|c|c|}
\hline & \multicolumn{5}{|c|}{ a. Use } & \multicolumn{4}{|c|}{$\begin{array}{l}\text { b. Required Level of } \\
\text { mastery }\end{array}$} & \multicolumn{4}{|c|}{$\begin{array}{l}\text { c. Where } \\
\text { primarily learned }\end{array}$} \\
\hline & & & $\ldots$ & to a & igh & $\mathrm{n}$ & s & $g$ & $\mathrm{p}^{*}$ & $\mathrm{e}$ & w & 0 & $\mathrm{n}^{* *}$ \\
\hline Professional theoretical knowledge & 1 & 2 & 3 & 4 & 5 & 1 & 2 & 3 & 4 & 1 & 2 & 3 & 4 \\
\hline Professional methods and techniques & & 2 & 3 & 4 & 5 & 1 & 2 & 3 & 4 & 1 & 2 & 3 & 4 \\
\hline Computer use & 1 & 2 & 3 & 4 & 5 & 1 & 2 & 3 & 4 & 1 & 2 & 3 & 4 \\
\hline Dealing with numbers & 1 & 2 & 3 & 4 & 5 & 1 & 2 & 3 & 4 & 1 & 2 & 3 & 4 \\
\hline Communication skills & 1 & 2 & 3 & 4 & 5 & 1 & 2 & 3 & 4 & 1 & 2 & 3 & 4 \\
\hline Working in a team & 1 & 2 & 3 & 4 & 5 & 1 & 2 & 3 & 4 & 1 & 2 & 3 & 4 \\
\hline Planning and organising & 1 & 2 & 3 & 4 & 5 & 1 & 2 & 3 & 4 & 1 & 2 & 3 & 4 \\
\hline Leadership skills & 1 & 2 & 3 & 4 & 5 & 1 & 2 & 3 & 4 & 1 & 2 & 3 & 4 \\
\hline Independence & 1 & 2 & 3 & 4 & 5 & 1 & 2 & 3 & 4 & 1 & 2 & 3 & 4 \\
\hline Creativity & 1 & 2 & 3 & 4 & 5 & 1 & 2 & 3 & 4 & 1 & 2 & 3 & 4 \\
\hline Initiative & 1 & 2 & 3 & 4 & 5 & 1 & 2 & 3 & 4 & 1 & 2 & 3 & 4 \\
\hline Dealing with changes & 1 & 2 & 3 & 4 & 5 & 1 & 2 & 3 & 4 & 1 & 2 & 3 & 4 \\
\hline Accuracy & 1 & 2 & 3 & 4 & 5 & 1 & 2 & 3 & 4 & 1 & 2 & 3 & 4 \\
\hline International & 1 & 2 & 3 & 4 & 5 & 1 & 2 & 3 & 4 & 1 & 2 & 3 & 4 \\
\hline
\end{tabular}

Q2: List a maximum of 3 items that, according to you, have been sufficiently attended in education and three items that have, in your opinion insufficiently been attended in education 
Sufficiently attended:

1 Item number ...

2 Item number ...

3 Item number .

Insufficiently attended:

1 Item number ...

2 Item number ..

3 Item number ... 


\section{Appendix B: Correlations between the competence items}

\section{Survey (significant correlations are shaded)}

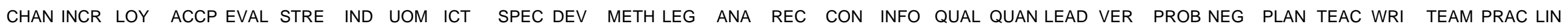
CHAN 1.00

\begin{tabular}{l|l|l} 
INCR & 0.54 & 1.00
\end{tabular}

LOY $\quad 0.48 \quad 0.40 \quad 1.00$

$\begin{array}{lllll}\text { ACCP } & 0.42 & 0.40 & 0.43 & 1.00\end{array}$

\begin{tabular}{l|l|l|l|l|l|l} 
EVAL & 0.46 & 0.46 & 0.57 & 0.43 & 1.00
\end{tabular}

$\begin{array}{llllllll}\text { STRE } & 0.53 & 0.46 & 0.48 & 0.50 & 0.43 & 1.00\end{array}$

$\begin{array}{lllllllll}\text { IND } & 0.47 & 0.60 & 0.37 & 0.43 & 0.41 & 0.46 & 1.00\end{array}$

$\begin{array}{lllllllll}\text { UOM } & 0.22 & 0.19 & 0.29 & 0.09 & 0.24 & 0.21 & 0.17 & 1.00\end{array}$

ICT $\quad \begin{array}{llllllllll}0.15 & 0.16 & 0.09 & 0.13 & 0.11 & 0.14 & 0.14 & 0.27 & 1.00\end{array}$

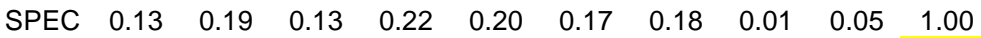

$\begin{array}{lllllllllllllll}\text { DEV } & 0.14 & 0.20 & 0.16 & 0.20 & 0.22 & 0.18 & 0.17 & 0.12 & 0.15 & 0.60 & 1.00\end{array}$

$\begin{array}{llllllllllllll}\text { METH } & 0.11 & 0.17 & 0.11 & 0.19 & 0.19 & 0.13 & 0.15 & 0.04 & 0.10 & 0.67 & 0.55 & 1.00\end{array}$

$\begin{array}{llllllllllllllll}\text { LEG } & 0.14 & 0.12 & 0.25 & 0.18 & 0.22 & 0.20 & 0.12 & 0.25 & -0.02 & 0.33 & 0.39 & 0.28 & 1.00\end{array}$

$\begin{array}{lllllllllllllll}\text { ANA } & 0.13 & 0.20 & 0.11 & 0.16 & 0.21 & 0.10 & 0.17 & 0.13 & 0.18 & 0.22 & 0.23 & 0.28 & 0.06 & 1.00\end{array}$

$\begin{array}{lllllllllllllllll}\text { REC } & 0.15 & 0.17 & 0.17 & 0.07 & 0.22 & 0.10 & 0.12 & 0.30 & 0.19 & 0.08 & 0.16 & 0.12 & 0.14 & 0.36 & 1.00\end{array}$

$\begin{array}{lllllllllllllllll}\text { CON } & 0.41 & 0.39 & 0.41 & 0.32 & 0.37 & 0.41 & 0.39 & 0.27 & 0.12 & 0.13 & 0.15 & 0.09 & 0.18 & 0.10 & 0.12 & 1.00\end{array}$

$\begin{array}{llllllllllllllllll}\text { INFO } & 0.21 & 0.21 & 0.18 & 0.26 & 0.20 & 0.18 & 0.20 & 0.21 & 0.25 & 0.06 & 0.08 & 0.07 & 0.08 & 0.17 & 0.20 & 0.21 & 1.00\end{array}$

$\begin{array}{llllllllllllllllllll}\text { QUAL } & 0.14 & 0.19 & 0.13 & 0.15 & 0.22 & 0.10 & 0.16 & 0.17 & 0.18 & 0.18 & 0.21 & 0.24 & 0.09 & 0.55 & 0.51 & 0.10 & 0.22 & 1.00\end{array}$

$\begin{array}{llllllllllllllllllllll}\text { QUAN } & 0.09 & 0.12 & 0.08 & 0.17 & 0.14 & 0.09 & 0.11 & 0.14 & 0.22 & 0.16 & 0.18 & 0.21 & 0.11 & 0.44 & 0.41 & 0.05 & 0.21 & 0.56 & 1.00\end{array}$

$\begin{array}{lllllllllllllllllllllll}\text { LEAD } & 0.23 & 0.22 & 0.22 & 0.07 & 0.24 & 0.22 & 0.14 & 0.28 & 0.14 & 0.07 & 0.11 & 0.07 & 0.14 & 0.11 & 0.29 & 0.21 & 0.15 & 0.16 & 0.13 & 1.00\end{array}$

$\begin{array}{llllllllllllllllllllllll}\text { VER } & 0.31 & 0.35 & 0.33 & 0.24 & 0.33 & 0.32 & 0.31 & 0.30 & 0.17 & 0.13 & 0.20 & 0.10 & 0.20 & 0.13 & 0.22 & 0.45 & 0.23 & 0.18 & 0.13 & 0.26 & 1.00\end{array}$

$\begin{array}{lllllllllllllllllllllllllll}\text { PROB } & 0.35 & 0.40 & 0.32 & 0.32 & 0.34 & 0.36 & 0.37 & 0.20 & 0.18 & 0.18 & 0.19 & 0.16 & 0.11 & 0.22 & 0.15 & 0.48 & 0.25 & 0.19 & 0.14 & 0.22 & 0.32 & 1.00\end{array}$

$\begin{array}{llllllllllllllllllllllllllll}\text { NEG } & 0.26 & 0.26 & 0.31 & 0.12 & 0.24 & 0.29 & 0.20 & 0.37 & 0.16 & 0.02 & 0.11 & -0.03 & 0.24 & -0.02 & 0.22 & 0.38 & 0.17 & 0.06 & 0.10 & 0.35 & 0.49 & 0.23 & 1.00\end{array}$

$\begin{array}{lllllllllllllllllllllllllll}\text { PLAN } & 0.31 & 0.33 & 0.33 & 0.17 & 0.30 & 0.31 & 0.27 & 0.42 & 0.20 & 0.03 & 0.10 & 0.01 & 0.16 & 0.08 & 0.28 & 0.38 & 0.28 & 0.14 & 0.12 & 0.46 & 0.43 & 0.31 & 0.55 & 1.00\end{array}$

$\begin{array}{llllllllllllllllllllllllll}\text { TEAC } & 0.25 & 0.22 & 0.24 & 0.14 & 0.28 & 0.21 & 0.17 & 0.23 & 0.13 & 0.11 & 0.14 & 0.12 & 0.15 & 0.17 & 0.21 & 0.28 & 0.20 & 0.17 & 0.11 & 0.41 & 0.26 & 0.30 & 0.21 & 0.30 & 1.00\end{array}$

$\begin{array}{llllllllllllllllllllllllllllll}\text { WRI } & 0.24 & 0.30 & 0.27 & 0.24 & 0.30 & 0.25 & 0.28 & 0.27 & 0.19 & 0.13 & 0.18 & 0.09 & 0.19 & 0.17 & 0.26 & 0.33 & 0.27 & 0.21 & 0.15 & 0.19 & 0.62 & 0.27 & 0.34 & 0.35 & 0.20 & 1.00\end{array}$

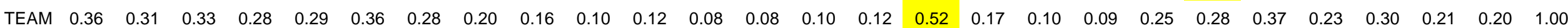

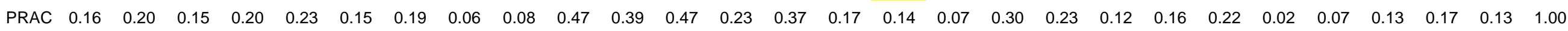

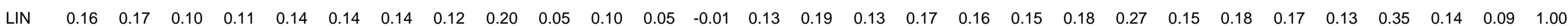


1999 Survey (significant correlations are shaded)

CREA COM INIT INTO LEAD ACCU ICT PLAN NUM TEAM CHAN SPEC METH IND

$\begin{array}{lllllllllllllllll}\text { CREA } & 1.00 & & & & & & & & & & & & & & & \\ \text { COM } & 0.22 & 1.00 & & & & & & & & & & & \\ \text { INIT } & 0.47 & 0.38 & 1.00 & & & & & & & & & & \\ \text { INTO } & 0.17 & 0.07 & 0.14 & 1.00 & & & & & & & & & \\ \text { LEAD } & 0.24 & 0.22 & 0.27 & 0.17 & 1.00 & & & & & & & & \\ \text { ACCU } & 0.10 & 0.11 & 0.19 & 0.09 & -0.05 & 1.00 & & & & & & & \\ \text { ICT } & 0.07 & 0.00 & 0.07 & 0.13 & -0.03 & 0.16 & 1.00 & & & & & & \\ \text { PLAN } & 0.28 & 0.42 & 0.40 & 0.13 & 0.34 & 0.15 & 0.07 & 1.00 & & & & & \\ \text { NUM } & 0.06 & -0.03 & 0.12 & 0.15 & 0.15 & 0.18 & 0.34 & 0.09 & 1.00 & & & & \\ \text { TEAM } & 0.20 & 0.39 & 0.28 & 0.08 & 0.28 & 0.14 & 0.02 & 0.34 & 0.02 & 1.00 & & & \\ \text { CHAN } & 0.35 & 0.36 & 0.49 & 0.15 & 0.27 & 0.17 & 0.04 & 0.37 & 0.07 & 0.33 & 1.00 & & \\ \text { SPEC } & 0.16 & 0.10 & 0.14 & 0.04 & 0.05 & 0.18 & 0.01 & 0.07 & 0.07 & 0.08 & 0.12 & 1.00 & \\ \text { METH } & 0.15 & 0.06 & 0.12 & 0.06 & 0.06 & 0.16 & 0.01 & 0.06 & 0.09 & 0.08 & 0.12 & 0.63 & 1.00 & \\ \text { IND } & 0.33 & 0.26 & 0.43 & 0.08 & 0.10 & 0.24 & 0.10 & 0.30 & 0.08 & 0.10 & 0.29 & 0.14 & 0.11 & 1.00\end{array}$

